\title{
A Reading of Ashes (Odczytanie popiołów)
}

Author: Jerzy Ficowski

First Published: 1979

Translations: English (A Reading of Ashes, 1981); French (Déchiffrer les cendres, 1981); Hebrew (Kri'at efer-mikle, 1985); German (Aus der Asche gelesen, 1986); Swedish (Att läsa i aska, 1987); Yiddish (Dos leyenen di ashen, 1992); Portugese (A leitura das cinzas, 2018).

About the Author: Jerzy Ficowski (1924-2006) was a poet, children's author, songwriter, essayist, prose writer, translator, and expert on Romani culture (in 1948-1950 he wandered with Polish Romani people). During the Nazi occupation, he stayed mainly in Warsaw and continued to study in clandestine schools. As a soldier of the Home Army (Armia Krajowa) he fought in the Warsaw Uprising of 1944 and was held prisoner in Gestapo jails and war camps. After the war, he studied philosophy and sociology at the University of Warsaw. He started writing in 1942, making his literary debut in a 1946 issue of the magazine Dzis $i$ Jutro with the poem To Blue Birds (Ptakom niebieskim). However, he had previously written about the Holocaust as an eyewitness. Manuscripts of his poems from 1943-1948, including the cycle Seven Poems (Siedem Wierszy), In the Former Ghetto (W byłym getcie), Jehovah, and Smile in the Oratory, are kept at the Krasiński Library in Warsaw (Kuczyńska-Koschany, 2017, pp. 338350). His first volume of poems, Tin Soldiers, was published in 1948. As a signatory of Memoriat 59 (1975, against changes in the Constitution of the Polish People's Republic), and a member of the opposition Workers' Defence Committee, Ficowski was officially banned as a writer in 1976-1980.

Further Important Publications: Ołowiani żotnierze (Tin Soldiers, 1948; poems); Moje strony świata (My World Directions, 1957; poems); Makowskie bajki (Makowski's Tales, 1959; poems); Cyganie na polskich drogach (Gypsies on Polish Roads, 1965; reflections); Regiony wielkiej herezji. Szkice o życiu i twórczości Brunona Schulza (Areas of Great Blasphemy: Sketches about Life and Output of Bruno Schulz, 1967; essays); Ptak poza ptakiem (Bird out of a Bird, 1969; poems); Czekanie na sen psa (Waiting the Dog To Sleep, 1970; proses); Errata (1981; poems); Śmierć jednorożca (The Death of an Unicorn, 1981; poems); Pantareja (2006; poems).

\section{Content and Interpretation}

Jerzy Ficowski's most famous collection of poetry, A Reading of Ashes, which has gone through seven Polish editions and is one of the most highly regarded volumes of Polish Holocaust poetry, was first published by the Association of Jews of Polish Origin in Great Britain in 1979, and in 1980 in Warsaw by the Independent Publishing House

Ә Open Access. () 2021 Katarzyna Kuczyńska-Koschany, published by De Gruyter. (c))BY-NC-ND This work is licensed under a Creative Commons Attribution-NonCommercial-NoDerivatives 4.0 License. https://doi.org/10.1515/9783110671056-085 
NOWA. The title evokes an activity that is both impossible and necessary: impossible, because the Holocaust cannot be fully understood and the victims do not have individual graves; necessary, because the Holocaust is a turning point in human history, a measure of all other genocides, and because it is only by attempting to represent and understand the mass extermination of European Jews that one is able to imagine the future of the world. A Reading of Ashes is an attempt to invent a language to describe completely new things, as well as an expression of helplessness and genuine repentance.

The author claimed he wrote the poems collected in this volume because, while he did not belong to the "doomed species", he was an eyewitness to the genocide (Kandziora, 2017, p. 21). Ficowski wrote them over a period spanning more than a quarter century, starting in 1952 with (one verse of) the poem Both Your Mothers. A thorough demonstration of Ficowski's poetic idiom and human sensitivity (pp. 3536), the collection is widely regarded in critical circles as one of the greatest poetic testimonies of the Holocaust. According to the poet's monographer, Ficowski builds two important artistic concepts here based on what he calls the "subject to silence". Firstly, he places someone else's words (quotes from survivors' statements) at the centre of the poem. Secondly, he does not look for words that are adjacent to reality, words that are more or less precise, more or less adequate, as he has lost all trust in this aspect of language in the face of Shoah (pp. 39-40). He renounces the poetic act of naming, the expression of pathos, preferring the rule of "fewest words" (p. 46) - a state of silence which is also a function of the unspeakable, and that everywhere characterises the Holocaust (A Six-Year-Old-From the Ghetto, Begging on Smolna Street in 1942). These two rules are most visibly at work in A Reading of Ashes where Ficowski traces the wartime fate of Jewish characters, his story of Rose Gold, for example (Letter to Marc Chagall), who survived 18 months trapped in a forest bunker (p. 40). But it is also at work in the terrifying language of those who pilfer "post-Jewish" property, ruthlessly and without reflection, as if to rescind the very fact of the people who formerly owned it, along with their memory - "post-Jewish" thus becoming synonymous with "post-human”. There are likewise certain locations, such as the Muranów towers, that seem to be susceptible to the act of erasure.

Another group of poems - A Reading of Ashes, The Way to Jerusalem, What Is, Posthumous Landscape, Execution of Memory, and Ending the Rite - can be seen as "images of murdered arcadia" (p. 46). As Leonard Neuger has observed (Neuger, 1989, pp. 75-89), the title of Ficowski's collection has come to signify a broader effort in Polish poetry to renew the memory of Jewish victims of the Holocaust - in the works of Miłosz, Kamieńska, Szymborska, and Różewicz, for example - by recalling Jewish words and characters (Jankiel, Korczak). In A Reading of Ashes, this tendency is most pronounced in such poems as An Epitaph for the Dead Alive, and The Assumption of Miriam from a Winter Street, 1942, In Memory of Janusz Korczak. In addition to the imperative to remember, there is also an effort - here at the very epicentre of the Holocaust - to safeguard the names of victims, even if it this effort is only made "behind- 
hand". In this way, Ficowski's narrative of Shoah oscillates between "I remember" and "I save" (Kandziora, 2017, pp. 50-53).

\section{Main Topics and Problems}

The expression "reading of ashes" has proven so apt that it has entered the post-Holocaust Polish language, becoming one of the most important formulations regarding the memory of the extermination of Jews. The same is true of the formulation "postJewish”. The poet thus consciously revises the Mediterranean and Polish “topos”, recalling people and places both real and symbolic, metaphorical and geographic: Jerusalem and the Wailing Wall, the Assumption of Miriam/Mary, the contradictory figure of the "dead alive" or "living corpse", the metonymous treatment of Janusz Korczak and the orphans he accompanied to the Treblinka extermination camp, a vision of the Warsaw district of Muranów (built on the ruins of the Warsaw Ghetto), the figure of the Jewish mother (Both Your Mothers), and finally Jew Jankiel, transformed into a Polish national topic as jankiel (the appelativum in the place of the nomen proprium thus conveying the multitude of Holocaust victims in Jankiel's image).

In Ficowski's poetry, as M. Sprusiński points out (1971), "The world has been transformed into a memorial site.” A Reading of Ashes has had a significant influence on the way other poets (Henefeld-Ron, 1979, p. 68) as well as artists (J. Marciniak, for instance) deal with the commemoration of the Holocaust.

\section{Cited Works}

Henefeld-Ron, I. (1979). Mowa matki - mowa syna. Oficyna poetów (London), (2), p. 68. Kandziora, J. (2017). Poeta w labiryncie historii. Studia o pisarskich rolach Jerzego Ficowskiego. Gdańsk: Fundacja terytoria książki. Neuger, L. (1989). Żydzi w powojennej poezji polskiej. Zeszyty Literackie, (26), pp. 75-89.

\section{Further References}

Baron, M. (2014). Grzebanie grzebania. Archeolog i grabarz w twórczości Jerzego Ficowskiego. Katowice: Wydawnictwo Uniwersytetu Śląskiego. Czwordon, P. (2010). Empatia i obserwacja. O poezji Jerzego Ficowskiego. Poznań: Wydawnictwo Poznańskie. Czyżewski, K. (2008). “Nie można tak po prostu...”, czyli droga Jerzego Ficowskiego do odczytania popiołów. In: K. Czyżewski, Linia powrotu. Zapiski z pogranicza. Sejny: Pogranicze, pp. 357-370. English available at: https://www.academia.edu/5791601/ Ficowski-Reading_the_Ashes [Accessed: 26.09.2020]. Głębicka, E. (1994). Ficowski Jerzy. In: J. Czachowska, A. Szałagan, eds., Wspótcześni polscy pisarze i badacze literatury, t. II. Warszawa: Wydawnictwa Szkolne i Pedagogiczne, pp. 291-296. Gross, N. (1979). Jerzy Ficowski czyta z popiołów. Tydzień Polski (London), (26), p. 6. Hajduk, A. (2016). "Hosanna uniesiona na samo dno" - ironia w Odczytaniu popiołów Jerzego Ficowskiego. Annales Universitatis Paedagogicae Cracoviensis. Studia Historicolitteraria, (16), pp. 182-190. Kandziora, J. (2010). Jerzy Ficowski. Bibliografia za lata 19472009. Sejny: Pogranicze. Kielanowski, L. (1980). “Odczytanie popiołów”. Tydzień 
Polski (London), (32), p. 12. Kobielska, M. (2010). Nastrajanie pamięci: artykulacja doświadczenia w poezji Jerzego Ficowskiego. Kraków: Universitas. Kuczyńska-Koschany K. (2016). Ważki i Zagłada. Annales Universitatis Paedagogicae Cracoviensis. Studia Historicolitteraria, (16), pp. 94-106. Leociak, J. (1993). Pielgrzymka słów. “Odczytanie popiołów” po żydowsku. Tygodnik Powszechny, (5), p. 11. Rapacka-Furtek, A. (1985). Ficowskiego “odczytanie popiołów”. Poezja, (7-8), pp. 123-125. Sommer P. (2010). Wcielenia Jerzego Ficowskiego wedtug recenzji, szkiców i rozmów z lat 1956-2007. Sejny: Pogranicze. Wygodzki, S. (1979). Odczytanie popiołów. Wiadomości (London), (31), p. 2. Weissbort, D. (1991). The Poetry of Survival: post-war Poets of Central and Eastern Europe. London: Anvil Press Poetry. Available at: https://www.encyclopedia. com/arts/encyclopedias-almanacs-transcripts-and-maps/reading-ashes-poems-odczytanie-popiolow [Accessed: 26.09.2020].

KKK 